\title{
A Sociological Approach to Misappropriation
}

\author{
Elizabeth A. Rowe*
}

\section{INTRODUCTION}

Social science and law are not strangers. In analyzing legal issues, scholars have often utilized theoretical or methodological approaches from the social sciences. While economics appears to be the prevalent branch of social science in legal analysis, ${ }^{1}$ sociology, with its focus on group (as opposed to individual) behavior, can be a suitable approach where, for instance, the application and interpretation of the law is based largely on contextual factors and on behavior. Trade secret law is one of these areas. Public policy arguments and value judgments loom large in these cases. Trade secret law regulates commercial ethics and morality, and the very doctrine of misappropriation is based on breach of good faith or breach of confidence. ${ }^{2}$ Sociological analysis can therefore offer valuable insights into trade secret misappropriation and improve our understanding of social factors involved in the complex interplay between legal doctrine and compliance.

This Article breaks new ground by applying sociological analysis to trade secret law. It uses a group which constitutes the largest segment of the workforce, namely, those labeled Generation X and Generation Y (collectively referred to and coined in the Article as "New Generation Employees") as a case study for analyzing how values and social norms influence compliance with trade secret laws. Unlike the Baby Boomers, these New Generation Employees are more likely to change jobs quickly,

* Associate Professor of Law, University of Florida, Levin College of Law. I am grateful to Mary Jane Angelo, Victoria Cundiff, Andrea Matwyshyn, Bill Page, Sharon Rush, Katheryn Russell-Brown, and Richard Shell for reviewing drafts or sharing various insights on this topic. My thanks also to participants at the 2008 Intellectual Property Scholars Conference at Stanford Law School and to faculty of the Legal Studies and Ethics Department at the Wharton School of Business for their comments on this paper. For excellent research assistance, I am very grateful to Stephanie Dullard, as well as to Mi Zhou, Constance Jones, Abbey Morrow, and Jonathan Blocker who later assisted on parts of the project. Finally, thank you to the University of Florida, Levin College of Law for its research support. (1997).

1. Ian Ayres, Never Confuse Efficiency with a Liver Complaint, 1997 WIS. L. REV. 503, 504

2. See infra Part III.B. 
protect and prioritize their self-interests, expect immediate gratification and rewards from employers, start their own companies, and use technology with great ease. ${ }^{3}$ They tend to feel little loyalty toward employers, and the current economic crisis, which further lessens expectations of job security, serves to underscore their lack of loyalty. Taken together, their attitudes and behaviors are especially noteworthy because they map closely to the narratives that are often present in trade secret misappropriation cases.

By drawing on the sociological literature, the Article is the first to apply theories about employee theft to trade secret misappropriation. It integrates the values of New Generation Employees with principles of equity theory, work climate theory, and societal change theory in a framework that (a) offers some insights into what motivates employees to misappropriate trade secrets and (b) offers corresponding general preventive measures to protect trade secrets in the workplace. It also explores how New Generation Employees' values and norms could test existing legal doctrine related to trade secret misappropriation, ownership, and liability.

Finally, the Article considers the broader usefulness of using this kind of sociological analysis beyond the workplace and beyond trade secret law. For example, changes in attitude about intellectual property in general might have implications for protection, compliance, and enforcement norms in the United States. Moreover, the approach may also be of benefit in addressing the frustrations United States companies experience in dealing with the foreign enforcement of their intellectual property rights in developing countries.

This Article proceeds in eight parts. Part II provides background on the New Generation Employees and summarizes the characteristics of Generation X and Generation Y. Part III of the Article provides a relevant overview of trade secret law, especially as it relates to the employment relationship. Part IV illustrates how the attitudes and behaviors of New Generation Employees are reflected in the narratives of trade secret cases and explores the significance of that observation. Part V introduces a connection between sociological theories of employee theft and trade secret law and applies those theories using New Generation Employees as the medium. Part VI explores the ways in which New Generation Employees may influence the doctrinal development of trade secret law, and Part VII suggests that a sociological perspective could offer benefits to intellectual property law generally.

3. See infra Parts II.A-II.B. 
Finally, the Article concludes in Part VIII, noting that understanding the sociological dimension to trade secret misappropriation is a valuable part of the complex process of achieving optimal protection for trade secrets.

\section{UNDERSTANDING NEW GENERATION EMPLOYEES}

As the early Baby Boomers ${ }^{4}$ have retired, ${ }^{5}$ a new crop of workers has replaced them. These New Generation Employees span two generations, Generation X and Generation Y, and they constitute the majority of the workforce in the United States today. ${ }^{6}$ Generation $\mathrm{X}$ refers to those individuals born between approximately 1965 and $1976 .^{7}$ Today they are in their early thirties to early forties. They number about fifty million. ${ }^{8}$ Members of Generation Y, on the other hand, are in their twenties. Also sometimes referred to as Echo Boomers (because they are about the same population size as Baby Boomers $)^{9}$ or Millennials, this group was born from 1978 to $1989 .^{10}$ They are the fastest growing segment of the workforce $^{11}$ and include approximately seventy-six million people. ${ }^{12}$

One explanation for the much larger size of Generation Y relative to Generation $\mathrm{X}$ has to do with the changes in rates of abortion and infertility treatments in the $1980 \mathrm{~s} .{ }^{13}$ Gen Xers are said to have been born during an "anti-child" period in United States history. ${ }^{14}$ One author notes that Gen X "is the most aborted generation in American history,",

4. The Baby Boomers are those born between the years circa 1946 to 1964. Gary O'Bannon, Managing Our Future: The Generation X Factor, 30 Pub. Personnel MgMt. 95, 95 (2001).

5. Penelope Trunk, What Gen Y Really Wants, TIME, July 5, 2007, available at www.time.com/time/printout/0,8816,1640395,00.html.

6. Executive Summary: Managing the Generation Mix 2007, 3 (2006) [hereinafter Managing the Generation Mix], http://www.rainmakerthinking.com/pdf\%20files/mix2007.pdf.

7. Stephanie Armour, Generation Y: They've Arrived at Work with a New Attitude, USA TODAY, Nov. 6, 2006, at 1B. Some researchers define the generation by those born between 1965 and 1981. See, e.g., Breda Bova \& Michael Kroth, Workplace Learning and Generation X, 13 J. WORKPlaCe LEARNing 57, 57 (2001). Others use the period 1961 to 1981. See O'Bannon, supra note 4 , at 95 .

8. Trunk, supra note 5 .

9. Pallavi Gogoi, Welcome to the Gen Y Workplace, Bus. WK., May 4, 2005, http://www. businessweek.com/bwdaily/dnflash/may2005/nf2005054_4640_db_083.htm.

10. Armour, supra note 7. There is some debate about the birth years covered by Generation Y. Some consider a wider period, those born between 1977 and 2002, as Gen Yers. Id. Others frame the generation by those born from 1977 to 1997. Gogoi, supra note 9.

11. Armour, supra note 7; Managing the Generation Mix, supra note 6.

12. Trunk, supra note 5.

13. William Strauss \& Neil Howe, Generations: The History of America's Future, 1584 TO 2069 , at $324,341-42$ (1991).

14. Managing the Generation Mix, supra note 6, at 12.

15. STRAUSS \& Howe, supra note 13 , at 324 . 
but by 1980 the abortion rate slowed and infertility treatment rates saw a significant increase in the $1980 \mathrm{~s} .{ }^{16}$

This Article refers to both Generation $\mathrm{X}$ and Generation $\mathrm{Y}$ collectively as "New Generation Employees." For the limited purposes of this Article, the relevant traits of these two groups are sufficiently similar to refer to them collectively in subsequent sections. As an introduction for the reader, however, what follows immediately below are separate descriptions of each generation. The Generation $\mathrm{X}$ and Generation Y labels are recognized outside the United States as well, and described with very similar characteristics. ${ }^{17}$ This Article, however, focuses on trade secret misappropriation in the United States.

\section{A. Generation $X$}

These are the children of the Baby Boomers. ${ }^{18}$ Some Baby Boomers have a negative impression of Gen Xers, calling them the "slacker" generation and accusing them of being "'disloyal,' 'arrogant,' 'cynical,' and 'lazy." "19 On the other hand, Gen Xers are more likely to describe themselves as '“ambitious,' 'determined,' and 'independent.",20 Research has shed some light on the picture of this generation and the conditions that have led to its members' mindset, demonstrating in the process that there is a more complex story behind the negative labels.

Over forty percent of this generation grew up in single parent homes, in part as a result of the high divorce rates during that period. ${ }^{21}$ Some call them "the most unsupervised generation.",22 They were latchkey kids, with television as a babysitter, believed to have been most influenced by growing up with divorced parents or in homes where both parents worked. ${ }^{23}$ "For many Xers, the American Dream is a stable

16. Neil Howe \& William Strauss, Millennials Rising: The NeXt Great Generation, 7 (2000) ("During the Gen-X child era, planned parenting almost always meant contraceptives or abortions; during the Millennial childhood, it more often means visits to the fertility clinic.").

17. See, e.g., Belinda Cranston, Talkin' 'Bout Their Generations, B \& T WKLY., May 2, 2008, at 10, available at 2008 WLNR 8764173 (discussing Generation X and Y in Australia); Sandra Davie, Gen.Y@Work, STRAITs Times (SINGAPORE), May 10, 2008, available at WLNR 8777147 (discussing Generation $\mathrm{X}$ and $\mathrm{Y}$ in Singapore).

18. Betty R. Kupperschmidt, Understanding Generation X Employees, 28 J. NURSING ADMIN. 36, 36 (1998).

19. O'Bannon, supra note 4, at 101. See also Kupperschmidt, supra note 18, at 36.

20. O'Bannon, supra note 4, at 105 (citing S. Craig, AfTer THE BoOM: THE POlitics of GENERATION X (1997)).

21. See id. at 98; Kupperschmidt, supra note 18, at 36-37.

22. Managing the Generation Mix, supra note 6, at 12.

23. Kupperschmidt, supra note 18 , at 37. 
family." 24 This seems to have affected their attitude toward work in that they want balance. They do not want work to be all consuming because they want time for themselves and their families. ${ }^{25}$ They had to learn at an early age to fend for themselves, and learned to be resourceful and independent along the way. ${ }^{26}$ They have an entrepreneurial spirit and view themselves "more as independent contractors rather than employees."27 Gen Xers did not develop strong connections to social institutions such as churches, schools, or corporations, and are distrustful of these institutions. ${ }^{28}$ They came of age at a time when they were surrounded by pictures of missing children on milk cartons, posters instilling fear of AIDS, stories of sexual abuse cases at daycare centers, and cases of police brutality unfolding on television. ${ }^{29}$

\section{Loyalty to Employers}

"Job-hopping is a normal, accepted method of career advancement for Generation Xers." ${ }^{30}$ Indeed, the perception is that one is penalized for remaining a long term employee of a company, because he or she forgoes the pay increases that come from job-hopping. ${ }^{31}$ This generation is motivated by money, learning, and lifestyle issues. ${ }^{32}$

While the high turnover rates among Gen Xers may be perceived as disloyalty, Gen Xers may see it differently. ${ }^{33}$ The comments of one Gen Xer to a researcher are telling of the view of that generation: "My attitude is that as long as I continue to be challenged and it's furthering my career goals, I'll stay with the company. If not, I'll move on. It's no [sic] an act of disloyalty, it's just the business of managing me and my career.", 34 To Gen Xers, switching jobs frequently is career flexibility,

24. O'Bannon, supra note 4, at 98 (citing M. Hornblower, Great Xpectations, TIME, June 9, 1997, at 23).

25. See id. at 100 (citing M. Kennedy, Generation Gap Thrives in the '90s, Kan. City StaR, Sept. 6, 1997, at C1).

26. Managing the Generation Mix, supra note 6, at 12.

27. O'Bannon, supra note 4, at 100 (citing M. Kennedy, Generation Gap Thrives in the '90s, KAN. CitY STAR, Sept. 6, 1997, at C1).

28. Managing the Generation Mix, supra note 6, at 12.

29. Id.

30. Bova \& Kroth, supra note 7, at 57.

31. Id. at 59 .

32. Id. at 57 .

33. See O'Bannon, supra note 4 , at 100.

34. Bova \& Kroth, supra note 7, at 62. 
but to their Baby Boomer managers it reflects disloyalty and an attitude that a Gen Xer better get her way, otherwise she will leave. ${ }^{35}$

Their approach is influenced by having observed their parents penalized for loyalty to companies. ${ }^{36}$ Generation $X$ grew up watching their parents suffer from corporate downsizing and layoffs. ${ }^{37}$ As such, they came to believe early in their working lives that institutional employers may not be trusted to fulfill their promises. ${ }^{38}$ Many events contributed to this sentiment:

Generation X witnessed a record number of bankruptcies, Wall Street scandals, and massive corporate layoffs, with loss of high-wage jobs and benefits. They saw the demise of the old employment contract, the belief that job security came to employees who joined an organization, paid their dues, and were productive for an extended period of time, even the duration of their working years. ${ }^{39}$

Accordingly, Generation Xers now demand gratification for short-term sacrifices. ${ }^{40}$ They have a "free agent approach to [their] careers," they are independent, technologically savvy, and want it all now. ${ }^{41}$

\section{Technological Proficiency}

Generation $\mathrm{X}$ grew up during the computer revolution, ${ }^{42}$ witnessing new advancements in technology every few months. ${ }^{43}$ Personal computers entered the scene in the early 1980 s, and, as children, Gen Xers became the first generation to use multimedia technology at home and in school. ${ }^{44}$ They became skilled at using a wide range of technology. ${ }^{45}$ Generation $\mathrm{X}$ produced many technology entrepreneurs,

35. O'Bannon, supra note 4, at 100; Kupperschmidt, supra note 18, at 39.

36. O'Bannon, supra note 4, at 100 ("Xer childhood memories are haunting them, as they recall the selling out of their parents by former employers.").

37. Bova \& Kroth, supra note 7, at 57.

38. See id.

39. Kupperschmidt, supra note 18 , at 38.

40. Managing the Generation Mix, supra note 6, at 12 .

41. Bova \& Kroth, supra note 7, at 58.

42. Id. at 57 .

43. O’Bannon, supra note 4, at 98.

44. Kupperschmidt, supra note 18, at 38. See also Peter Leyden, The Bright Side: Where Were You When the PC Was Born?, STAR TRIB., June 18, 1995, at 6T (stating that members of Generation $\mathrm{X}$ "are the first generation that grew up learning computer skills and came of age surrounded by digital technologies").

45. Kupperschmidt, supra note 18 , at 36. 
including, for instance, many of the innovators behind Microsoft. ${ }^{46}$ Their technical proficiency has allowed Gen Xers to start businesses faster than might otherwise be possible. ${ }^{47}$

\section{B. Generation $Y$}

Offspring of the Baby Boomers and younger siblings of Gen Xers, ${ }^{48}$ the members of Generation Y have been described as "Generation X on

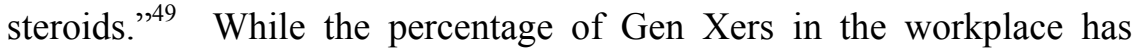
remained steady, it is expected that Gen Yers will outnumber Gen Xers in the workforce by $2010 .^{50}$ Gen Yers tend to be more optimistic about their future than Gen Xers, with about eighty percent of Gen Yers believing that they will be better off than their parents. ${ }^{51}$ Unlike previous generations, Gen Yers grew up in households where both parents worked and thus had higher disposable incomes. ${ }^{52}$ The consciousness of this generation was shaped by such events as the terrorist attacks of September 11, 2001 (preceded by the Oklahoma City, World Trade Center, and Atlanta Summer Olympics bombings) and school shootings, like Columbine. ${ }^{53}$ As a result, this appears to have made them more "introspective" than prior generations. ${ }^{54}$

As products of the most child-centered generation ever, Gen Yers have been pampered and nurtured by their parents. ${ }^{55}$ Some consider them an "overindulged, spoiled, and disengaged group that looks at the world through a prism of self interest." ${ }^{, 56}$ They are thus considered to be both "high-performance and high-maintenance." interested in long term rewards, and they reject such notions as climbing the corporate ladder, paying one's dues, and waiting to collect until

\footnotetext{
46. Id. at 38 .

47. O'Bannon, supra note 4, at 103.

48. Managing the Generation Mix, supra note 6, at 16.

49. Armour, supra note 7 (quoting researcher Bruce Tulgan in an interview).

50. Managing the Generation Mix, supra note 6, at 3.

51. Bruce Tulgan \& CARolyn A. Martin, Managing Generation Y: Global Citizens BORN IN THE LATE SEVENTIES AND EARLY EIGHTIES 4 (2001).

52. Gogoi, supra note 9.

53. Id.; Managing the Generation Mix, supra note 6, at 16 .

54. Gogoi, supra note 9.

55. Armour, supra note 7. See also HowE \& STRAUSS, supra note 16, at 33 ("Starting as babies, kids were now to be desperately desired, to be in need of endless love and sacrifice and care-and to be regarded by parents as the highest form of self-discovery.").

56. Gogoi, supra note 9.

57. Armour, supra note 7.
} 
retirement. ${ }^{58}$ Instead, they want it all today. ${ }^{59}$ While they believe they can add value today, they also want to be rewarded today for that value. ${ }^{60}$ Incentives, feedback, and rewards are, therefore, very important to this generation. $^{61}$

Their career choices are motivated by a desire to play meaningful roles while doing meaningful work. ${ }^{62}$ They enjoy working in collaboration with others and want to make a difference. ${ }^{63}$ They value creating relationships in the workplace and may feel stronger connections to coworkers than they do to the company itself. ${ }^{64}$ A survey of twenty-five to thirty-year-old attorneys revealed that this age group's wish list for their jobs included "time for personal life; opportunities for advancement; professional growth; achievement; intrinsic nature of work; security; leadership; and being a member of a team. ${ }^{\prime 65}$ This list is representative of the factors that motivate Gen Yers as a group.

Like Gen Xers, Gen Yers are also very entrepreneurial. ${ }^{66}$ Indeed, some believe that entrepreneurship is a safety net for Gen Yers. ${ }^{67}$ "'Instead of a simple 100-hour week, now the model is: work 60 hours a week, devote 20 hours to nonprofit, and spend 20 hours writing a plan to start your own business." 68 They are a very socially conscious generation, and volunteer activities are important to them. ${ }^{69}$ They enjoy

\footnotetext{
58. TULGAN \& MARTIN, supra note 51, at 21 .

59. Id.

60. Id.

61. Id. Researchers Bruce Tulgan and Carolyn Martin provide the following advice to meet the expectations of Generation Y: (1) provide challenging work that really matters; (2) balance clearly delegated assignments with freedom and flexibility; (3) offer increasing responsibility as a reward for accomplishments; (4) spend time getting to know staff members and their capabilities; (5) provide ongoing training and learning opportunities; (6) establish mentoring relationships; (7) create a comfortable, low-stress environment; (8) allow some flexibility in scheduling; (9) focus on work, but be personable and have a sense of humor; (10) balance the roles of "boss" and "team player"; (11) treat Gen Yers as colleagues, not as interns or "teenagers"; (12) be respectful, and call forth respect in return; (13) consistently provide constructive feedback; and (14) reward Gen Yers when they have done a good job. Id. at 52-62.

62. Id. at 13. See also Gogoi, supra note 9. Volunteering is important to members of Generation Y, and they prefer to work for companies that provide volunteer opportunities. See Trunk, supra note 5. "Members of this generation volunteer in their communities more than any other in American history." Gogoi, supra note 9.

63. Tulgan \& MARTIN, supra note 51, at 14. See also Armour, supra note 7.

64. See Leigh Jones, The 'Gen Y' Equation, NAT'L L.J., Feb. 28, 2005, at 12.

65. Id.

66. Tulgan \& Martin, supra note 51, at 17. See also Armour, supra note 7.

67. E.g., Trunk, supra note 5 .

68. Gogoi, supra note 9 (quoting Heidi Locke Simon, a partner in consulting firm Bain \& Co.).

69. Managing the Generation Mix, supra note 6, at 16.
} 
working for employers who are socially responsible and who give back to the community. ${ }^{70}$

\section{Loyalty to Employers}

Shaped by corporate scandals such as Enron and Arthur Andersen, Gen Yers are cynical about long-term commitments to employers. ${ }^{71}$ They believe that job security is a thing of the past and, as a result, feel little loyalty to their employers. ${ }^{72}$ Without a promise of job security, an employee must, therefore, look out for herself and be on the lookout for other job opportunities. ${ }^{73}$ "According to Gen Y, 'job security' means, I'll learn all I can here and, as soon as opportunities to keep on learning disappear, I'll look for a better position with another organization. Of course, I'll negotiate the best deals for my expanded skills, experiences, and knowledge." 74 Gen Yers are prone to changing jobs and careers very quickly, thus creating a revolving door effect for employers. ${ }^{75}$ They value creating relationships in the workplace, and may feel stronger connections to coworkers than they do to the company itself. ${ }^{76}$ Indeed, Gen Yers "will choose a job just to be with their friends.",77

\section{Technological Proficiency}

Gen Yers have never experienced life without computers. ${ }^{78}$ They are the digital generation who probably "were booting up computers long before they were hopping on bikes." "Th They grew up with the Internet, and they are very proficient and at ease with technology. ${ }^{80}$ They probably are more comfortable communicating via e-mail, text messages, and instant messages than by in-person meetings or phone calls. ${ }^{81}$ Indeed, they are quite adept at simultaneously using various kinds of

70. Id. at 17 .

71. See Armour, supra note 7.

72. Jones, supra note 64.

73. Benjamin Aaron \& Matthew Finkin, The Law of Employee Loyalty in the United States, 20 COMP. LAB. L. \& POL'Y J. 321, 340 (1999).

74. Managing the Generation Mix, supra note 6, at 17.

75. Armour, supra note 7. See also infra text of note 269 (illustrating company policies designed to retain Generation Y workers).

76. Jones, supra note 64.

77. Trunk, supra note 5.

78. TULGAN \& MARTIN, supra note 51, at 5.

79. Id. at 6 .

80. See Armour, supra note 7; Gogoi, supra note 9.

81. Armour, supra note 7. 
technology while working and can be "trading instant messages, listening to music, surfing the Web and checking e-mail, all while attending to the matters at hand." 82 As a result, they have been criticized for their short attention spans and the fact that they absorb information "in very short chunks." ${ }^{83}$

\section{RELEVANT TRADE SECRET PRINCIPLES}

A trade secret can be any business information that is secret and derives value from its secrecy. ${ }^{84}$ There is no federal statutory law governing trade secrets; they are protected by state law. Most states have adopted the Uniform Trade Secrets Act (UTSA), which provides some uniformity in defining trade secrets and trade secret misappropriation. The states that have not adopted the UTSA tend to rely on common law based on the Restatement of Torts. ${ }^{85}$

Under the UTSA, virtually anything of competitive value to a company can be a trade secret as long as it is kept secret. ${ }^{86}$ Accordingly, a wide range of confidential business information including customer lists, sales records, pricing information, and customer information can be protectable trade secrets. ${ }^{87}$ Some jurisdictions have also granted trade secret protection to secret contract terms, marketing strategies, and industry studies. ${ }^{88}$ Further, under the UTSA, a trade secret does not need

82. Gretchen Neels, Commentary: In Dealing with Gizmos, Tune Into Generational Needs, Mo. LAW. WKLY., April 28, 2008, available at http://www.accessmylibrary.com/coms2/summary_028634404935 ITM.

83. Gogoi, supra note 9.

84. UNIF. TRADE SECRETS ACT § 1(4) (amended 1985), 14 U.L.A. 538 (2005).

85. See Michael A. Epstein, Epstein on InTellectual Property $\S 1.02$ at $1-4$ (5th ed. 2009 Supp.). The Restatement (Third) of Unfair Competition now also governs trade secrets, and its rules apply to actions under both the UTSA and the Restatement of Torts. See Restatement (THIRD) OF UNFAIR COMPETITION § 39, reporters' note (1995).

86. UNIF. TRADE SECRETS ACT $\S 1(4)$. The UTSA requires reasonable efforts to protect the confidentiality of trade secrets. See Surgidev Corp. v. Eye Tech., Inc., 828 F.2d 452, 455 (8th Cir. 1987).

87. McFarland v. Brier, No. 96-1007, 1998 WL 269223, at *3 (R.I. Super. Ct. May 13, 1998).

88. See PepsiCo, Inc. v. Redmond, 54 F.3d 1262, 1265-70 (7th Cir. 1995) (finding strategic financial and marketing information to be protected trade secrets under the UTSA); ConAgra, Inc. v. Tyson Foods, Inc., 30 S.W.3d 725, 728-30 (Ark. 2000) (recognizing that Tyson's business information concerning production, marketing strategies, pricing programs, and contract terms are protectable trade secrets under the UTSA, but refusing to grant such protection for failure to maintain their secrecy). 
to be in use to be protected, and negative information ${ }^{89}$ - comprised of $^{2}$ failed research or an ineffective process-is also protected. ${ }^{90}$

Trade secret misappropriation ${ }^{91}$ occurs when a trade secret is acquired by a person who knows (or has reason to know) that the trade secret was obtained through improper means. "Improper means" under the UTSA includes, but is not limited to, theft, breach or inducement of a breach of a duty to maintain secrecy, or espionage through electronic or other means. ${ }^{92}$ Thus, a wide range of activities by employees can constitute misappropriation. An employer who has been harmed may have misappropriation claims, including civil claims and criminal penalties against the employee. However, these remedies may be unsatisfactory and unable to fully redress the destructive harm resulting from the loss of a trade secret. When a trade secret is disclosed and becomes generally known to others, it loses its status as a trade secret, and cannot be reclaimed. ${ }^{93}$ In addition, most employees, for instance, do not have deep pockets, limiting the amount of financial restitution available to cure the misappropriation. An even more serious problem is that if the trade secret information passes into the hands of a third party, such as a competitor or the press, the trade secret owner may not have any recourse against the third party or any ability to stop the dissemination or use. ${ }^{94}$

89. A negative trade secret is the knowledge of what not to do or what does not work, a lesson learned from a certain process or research and development effort that failed. See JAMES PoOLEY, TRADE SECRETS $§ 4.02[3]$ (1997).

90. See Roger M. Milgrim, Milgrim on TRAde Secrets § 1.01[2][a] (2009) (discussing the UTSA).

91. The UTSA defines "misappropriation" as:

(i) acquisition of a trade secret of another by a person who knows or has reason to know that the trade secret was acquired by improper means; or

(ii) disclosure or use of a trade secret of another without express or implied consent by a person who:

(A) used improper means to acquire knowledge of the trade secret; or

(B) at the time of disclosure or use, knew, or had reason to know, that his knowledge of the trade secret was:

(I) derived from, or through, a person who had utilized improper means to acquire it;

(II) acquired under circumstances giving rise to a duty to maintain its secrecy or limit its use; or,

(III) derived from, or through, a person who owed a duty to the person seeking relief to maintain its secrecy or limit its use; or

(C) before a material change of his position knew or had reason to know that it was a trade secret and that knowledge of it had been acquired by accident or mistake.

UNIF. TRADE SECRETS ACT § 1(2).

92. Id. § 1(1).

93. FMC Corp. v. Taiwan Tainan Giant Indus. Co., 730 F.2d 61, 63 (2d Cir. 1984).

94. See generally Elizabeth A. Rowe, Saving Trade Secret Disclosures on the Internet Through 


\section{A. Trade Secrets and the Employment Relationship}

An employer has a strong interest in protecting its valuable trade secrets, and trade secret theft continues to be a growing problem for businesses. ${ }^{95}$ Trade secret protection is often justified on the grounds that it would be unfair for one party to become enriched at the expense of another through theft of the latter's secrets. ${ }^{96}$ Employers also rely on the protections provided under trade secret law as an incentive to invest resources in the creation of trade secrets, and to share those secrets with employees. $^{97}$

Courts have consistently recognized an employer's right to protect and preserve trade secrets and confidential and proprietary information. ${ }^{98}$ An employer has a recognized business interest in protecting trade secrets disclosed in confidence to an employee during the course of his employment, even where there is no enforceable restrictive covenant between the parties. ${ }^{99}$ This is especially true where the employee was placed in a position of trust and responsibility by the employer. ${ }^{100}$

Ultimately, it is intimate knowledge of a company's inner workings that is of value to a competitor. That value to a competitor helps make the information a trade secret, and "[a] trade secret once lost is, of course, lost forever." ${ }^{01}$ A former employee may use the general knowledge, skills, and experience acquired during his employment, even in competition with his former employer. ${ }^{102}$ "This principle effectuates the public interest in labor mobility, promotes the employee's freedom to practice a profession, and freedom of competition."103 However, the

Sequential Preservation, 42 WAKE FOREST L. REV. 1, 14-17 (2007).

95. See, e.g., infra Parts IV.A-IV.C.

96. See Jerry Cohen \& Alan S. Gutterman, Trade Secrets Protection and EXPLOITATION 12 (1998).

97. See generally Paul Goldstein, Copyright, Patent, Trademark and Related State DOCTRINES 151-53 (4th ed. 1997).

98. See, e.g., New England Canteen Serv., Inc. v. Ashley, 363 N.E.2d 526, 528 (Mass. 1977); D.C. Wiring, Inc. v. Lamontagne, No. 91-1722, 1993 WL 818562, at **1-2 (Mass. Super. Ct. Dec. 20, 1993); Stevens \& Co. v. Stiles, 71 A. 802, 805 (R.I. 1909).

99. See, e.g., Stevens \& Co., 71 A. at 805.

100. See D.C. Wiring, 1993 WL 818562 , at *2 ("Courts have confirmed that businesses may protect confidential information by means of a covenant not to compete."); see also New England Canteen Serv., 363 N.E.2d at 528 (holding that an employer's interest in trade secrets, confidential data, and goodwill are entitled to protection).

101. FMC Corp. v. Taiwan Tainan Giant Indus. Co., 730 F.2d 61, 63 (2d Cir. 1984).

102. See CVD, Inc. v. Raytheon Co., 769 F.2d 842, 852 (1st Cir. 1985); RestatemEnT (THIRD) OF UNFAIR COMPETITION $\S 42 \mathrm{cmt}$. d (1995).

103. CVD, Inc., 769 F.2d at 852 . 
former employee may not use the confidential or trade secret information of the former employer. ${ }^{104}$

\section{B. The Confidential Nature of the Employment Relationship}

The general rule is that the employee stands in a confidential relationship with his or her employer with respect to the employer's confidences. $^{105}$ An employee's duty not to disclose the secrets of her employer may arise from either an express contract or may be implied from the confidential relationship existing between the employer and employee, and an employee may not use this information to the detriment of her employer. ${ }^{106}$ The courts have made clear that this protection applies to an employer's trade secrets even after the employee no longer works for the employer. ${ }^{107}$ Some courts view the employee's duty of confidentiality to the employer as a fiduciary obligation. ${ }^{108}$ While working for the employer, the employee owes a duty of loyalty to the employer and consequently must not behave in any manner that would be harmful to the employer. ${ }^{109}$

104. See Restatement (ThiRd) OF Unfair COMPetition $\S 42$ cmts. b-c (1995).

105. See E.I. DuPont de Nemours Powder Co. v. Masland, 244 U.S. 100, 102 (1917) (“defendant [employee] stood in confidential relations with the plaintiff's [former employer]").

106. BIEC Int'l, Inc. v. Global Steel Servs., Ltd., 791 F. Supp. 489, 548 (E.D. Pa. 1992) (citing Healthcare Affiliated Servs., Inc. v. Lippany, 701 F. Supp. 1142, 1152 (W.D. Pa. 1991); Anaconda Co. v. Metric Tool \& Die Co., 485 F. Supp. 410, 424 (E.D. Pa. 1980); Femlee v. Lockett, 351 A.2d 273, 276 (Pa. 1976); Air Prods. \& Chems., Inc., v. Johnson, 442 A.2d 1114, 1120 (Pa. Super. Ct. 1982)). See also Flotec, Inc. v. Southern Research, Inc., 16 F. Supp. 2d 992, 999 (S.D. Ind. 1998) ("The owner may disclose information in confidence to employees or others without losing the legal protection.").

107. L.M. Rabinowitz Co. v. Dasher, 82 N.Y.S.2d 431, 435 (N.Y. Sup. Ct. 1948) (“It is implied in every contract of employment that the employee will hold sacred any trade secrets or other confidential information which he acquires in the course of his employment." (citations omitted)); Air Prods. \& Chem., Inc., 442 A.2d at 1120 ("[A]n ex-employer can reasonably rely upon the obligation of its employees not to disclose trade secrets about which they obtained knowledge while working in a confidential relationship with that employer.").

108. See, e.g., Churchill Commc'ns Corp. v. Demyanovich, 668 F. Supp. 207, 211 (S.D.N.Y. 1987) (stating that even in the absence of a restrictive covenant, an employee's use of an employer's trade secrets can be enjoined when such conduct violates a fiduciary duty owed to the employer); Rubner v. Gursky, 21 N.Y.S.2d 558, 561 (N.Y Sup. Ct. 1940) (stating that a fiduciary duty not to disclose is implied in all employment contracts).

109. See Royal Carbo Corp. v. Flameguard, Inc., 645 N.Y.S.2d 18, 19 (N.Y. App. Div. 1996) (concluding a duty of loyalty was breached where employee surreptitiously organized competing entity and utilized former employer's customer lists); RESTATEMENT (SECOND) OF AGENCY § 387 (1958) ("Unless otherwise agreed, an agent is subject to a duty to his principal to act solely for the benefit of the principal in all matters connected with his agency."); see generally EMPLOYEE DUTY OF LOYAlty (Arnold H. Pedowitz et al. eds., 1995) (providing a comprehensive state-by-state survey). 


\section{CONNECTIONS TO CASE LAW NARRATIVES}

The reported case law generally does not provide the ages of the defendants in trade secret misappropriation cases. Accordingly, it is difficult to perform any kind of analysis that might accurately determine the extent to which members of Generation X and Generation $\mathrm{Y}$ are represented as alleged misappropriators. However, a subset of trade secret misappropriation cases, those federal criminal actions filed under the Economic Espionage $\mathrm{Act}^{110}$ (EEA), are more likely to report the ages of defendants. As discussed below, a simple review and analysis of the EEA cases indicate an overrepresentation of New Generation Employees in those misappropriation cases.

The remainder of this section provides a sampling of the circumstances that are often present in trade secret misappropriation cases. For instance, job dissatisfaction, job hopping, changes in corporate ownership, and the use of computer technology to store or transmit trade secrets are among the facts found in virtually all misappropriation cases. Thus, insofar as these circumstances map closely to the attitudes and behaviors of New Generation Employees, one can reasonably expect an upward trend in trade secret misappropriation as these individuals outnumber others in the workforce.

\section{A. New Generation Employees in the EEA Cases}

The Department of Justice issues press releases and tracks the number of cases prosecuted under the EEA. A review of that data revealed thirty-four indictments in the past seven years. Of those thirtyfour, twenty report the age(s) of the defendant(s), and eleven of those twenty include New Generation Employees. ${ }^{111}$ While this may be an interesting observation, the sample size is too small to yield statistically significant data, and does not permit one to draw any conclusions from the data itself at this time. Perhaps in a few years, a larger number of EEA cases might make a statistical evaluation more useful. In the meantime, however, that subset of cases is nonetheless useful because the misappropriation narratives in the EEA cases tend to be similar to those in the broader group of civil and criminal cases. Accordingly, it is

110. 18 U.S.C. $\S 1832$ (2006).

111. In those eleven cases at least one defendant was born after 1965. While some cases involved more than one defendant born after 1965, in order to be consistent, I counted the number of cases involving New Generation Employees, rather than the total number of New Generation Employee defendants. 
likely that a comparable trend would be reflected in the wider group of trade secret cases. A few illustrations of the type of conduct reflected in the EEA cases follow.

The cases almost all involve employees who obtained their employer's trade secrets and transferred them to a competitor. For example, a thirty-seven-year-old product development manager allegedly downloaded dozens of files containing confidential product information and transferred them to a competitor. ${ }^{112}$ A thirty-five-year-old design engineer transported stolen "data sheets" containing his employer's proprietary information to a potential foreign competitor. ${ }^{113} \mathrm{~A}$ thirtyfour-year-old employee stole his employer's back-up tapes and offered them for sale to a competitor. ${ }^{114}$ Finally, a thirty-two-year-old information technology specialist sold his employer's confidential information for three million dollars. ${ }^{115}$

Sometimes it is not employees who steal trade secrets, but third parties or others with access to information. In one case a nineteen-yearold college student stole sensitive trade secrets belonging to DirectTV while he was working for a copying service employed by DirectTV's outside counsel. ${ }^{116}$ In another case, two Harvard Medical School postdoctoral research fellows, both in their thirties, were accused of stealing marketable scientific information belonging to Harvard. ${ }^{117}$ They were accused of shipping more than thirty boxes of biologicals, books, and documents to a competing lab. ${ }^{118}$ They further collaborated with a Japanese company in the creation and sale of related and derivative

112. Press Release, United States Dep't of Justice, Silicon Valley Engineer Indicted for Stealing Trade Secrets and Computer Fraud (Dec. 22, 2005) [hereinafter United States Dep't of Justice, Silicon Valley Engineer Indicted], http://www.usdoj.gov/criminal/cybercrime/zhangIndict.htm.

113. Press Release, United States Dep't of Justice, Chip Design Engineer Pleads Guilty to Transporting Stolen Property of Silicon Valley Company to Taiwan (Sept. 6, 2005), http://www. usdoj.gov/criminal/cybercrime/tsaiPlea.htm.

114. Press Release, United States Dep't of Justice, Former IT Director of Silicon Valley Company Pleads Guilty to Theft of Trade Secrets (Apr. 1, 2005), http://www.usdoj.gov/criminal /cybercrime/woodwardPlea.htm.

115. Press Release, United States Dep't of Justice, Chicago, Illinois Man Pleads Guilty to Theft of Trade Secrets, Offered to Sell Online Interpreter's Information (Apr. 11, 2003) [hereinafter United States Dep't of Justice, Illinois Man Pleads Guilty], http://www.usdoj.gov/criminal/ cybercrime/sunPlea.htm.

116. Press Release, United States Dep't of Justice, L.A. Man Sentenced for Stealing Trade Secrets Pertaining to 'Smart Card' Technology (APR. 28, 2003), http://www.usdoj.gov/criminal /cybercrime/serebryanySent.htm.

117. Press Release, United States Dep't of Justice, Pair Charged with Theft of Trade Secrets from Harvard Medical School (June 9, 2002), http://www.usdoj.gov/criminal/cybercrime/zhu Charges.htm.

118. Id. 
products, and otherwise capitalized on the information. ${ }^{119}$ This kind of narrative is by no means unique to the EEA cases. Indeed, it is entirely consistent with the conduct that is often alleged in the civil trade secret misappropriation cases as well. The following two sections, which provide case examples of disgruntled employees and the use of technology to misappropriate, will further illustrate the pattern of misconduct that epitomizes these cases.

\section{B. Disgruntled Employees on the Move}

Even apart from the lack of loyalty common amongst the New Generation Employees, researchers have, for a while, noted a general decline in loyalty in the workplace. This decline stems, in part, from the changing nature of expectations in the workplace, particularly the lack of job security. ${ }^{120}$ Indeed, as this Article goes to press the United States is in the midst of a recession. As a result, New Generation Employees are experiencing first-hand the effects of high unemployment rates and massive layoffs. The expectation of long-term employment until retirement with any company is a thing of the past. ${ }^{121}$ Most full time employees change jobs several times over the span of their careers. ${ }^{122}$ That mobility, in itself, creates more opportunities for employees to transfer trade secrets to new employers or to their own competing ventures. ${ }^{123}$

Furthermore, dissatisfied and angry employees are likely to leave their companies quietly without discussing their departure with their employers, ${ }^{124}$ fueling the likelihood of misappropriation in the process. The case examples below demonstrate the kinds of scenarios that result when employees who are highly mobile and quick to join competitors or

119. Id.

120. Aaron \& Finkin, supra note 73 , at 339.

121. Katherine V.W. Stone, The New Psychological Contract: Implications of the Changing Workplace for Labor and Employment Law, 48 U.C.L.A. L. REV. 519, 541 (2001) ("It has been widely reported that large corporations no longer offer their employees implicit contracts for lifetime employment.").

122. See id. at 548 .

123. See generally Elizabeth A. Rowe, When Trade Secrets Become Shackles: Fairness and the Inevitable Disclosure Doctrine, 7 TUL. J. TECH. \& INTELL. PROP. 167, 183-91 (2005).

124. See William H. Turnley \& Daniel C. Feldman, The Impact of Psychological Contract Violations on Exit, Voice, Loyalty, and Neglect, 52 HUM. REL. 895, 917 (1999) (discussing the strong relationship between "psychological contract violations" and employee exit and offering the explanation "that there are fewer negative consequences (for employees themselves) associated with attempts to exit"). 
start their own competing ventures, become dissatisfied with their jobs or changes in corporate ownership.

Employees who feel that they are not paid well enough by their employers can be angry and resentful. In Lexis-Nexis v. Beer, an employee became dissatisfied with his compensation. ${ }^{125}$ After the employer refused several requests for a salary increase, the employee resigned and accepted employment with a competitor. ${ }^{126}$ Before he returned all office equipment provided by his former employer, he copied emails and the customer information database previously stored on a company laptop onto a zip disk. ${ }^{127} \mathrm{He}$ later transferred the information to a new laptop he received from his new employer. ${ }^{128}$

Layoffs can be a major source of dissatisfaction. In MicroStrategy, Inc. v. Business Objects, S.A., a software company experienced financial instability. ${ }^{129}$ When the company began to lay off its employees and shrink its businesses, several employees also planned their departure. ${ }^{130}$ In an effort to gain new employment, they disclosed confidential information to the number one competitor in the market ${ }^{131}$ and promised to "swing business" in return. ${ }^{132}$ As a result, the company lost a significant amount of trade secrets, including sales techniques, descriptions of software architecture, and competitive intelligence. ${ }^{133}$

Mergers gone badly can also feed discontent. In Hilb, Rogal \& Hamilton Co. of Atlanta v. Holley, an insurance agent merged his own professional agency with another company ${ }^{134}$ and became a shareholder employee. ${ }^{135}$ He later became dissatisfied with his new job after he learned that the merged company would no longer focus on his business specialty and he decided to leave. ${ }^{136} \mathrm{He}$ took with him an electronic organizer containing customers' contact information. ${ }^{137}$ By using that information, approximately twenty to twenty-five percent of the clients

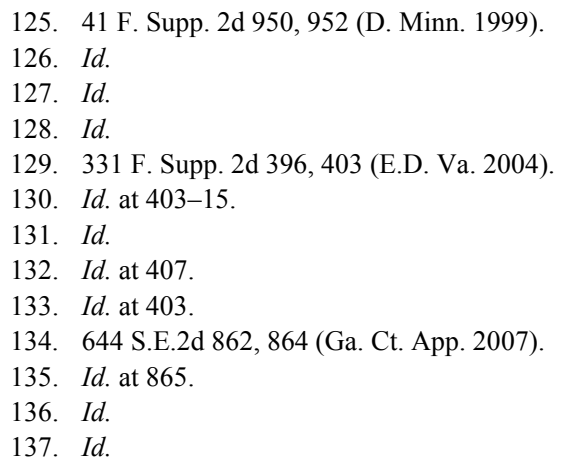


he serviced during his former employment followed him to his new employer. $^{138}$

In Anadarko Petroleum Corp. v. Davis, a petroleum engineer worked for the predecessor company for approximately twenty years. ${ }^{139}$ The predecessor company later merged into another corporation. ${ }^{140}$ After the change of ownership, the engineer became dissatisfied with his career. ${ }^{141}$ "He felt that he had been passed over for promotions and "pushed to the side ...." "142 $\mathrm{He}$ also believed that his supervisors knew less about the business than he did and were making " "poor decisions." 143 As a result, he joined a competitor and took trade secret information belonging to the former employer. ${ }^{144}$

Employees who form their own competing ventures often capitalize on their former employer's trade secrets to jump-start their businesses. In Latuszewski v. Valic Financial Advisors, Inc., several financial advisors formed their own competing business venture while they were still employed with the former employer. ${ }^{145}$ In order to move customers who represented millions of dollars in assets to their own business venture, these employees selectively targeted a group of customers and collected their customer data before submitting their resignations. ${ }^{146}$ Three months after leaving, they transferred ten million dollars in assets from the former employer. ${ }^{147}$

In Intellisports LLC $v$. Fitzgerald, a departing editor offered to buy one of the divisions owned by his employer publishing company. ${ }^{148}$ After his employer refused to sell the division, he resigned and started his own competing publication business. ${ }^{149} \mathrm{He}$ then obtained the employer's subscriber list from a former coworker and used it to solicit customers of his former employer to his publication. ${ }^{150}$

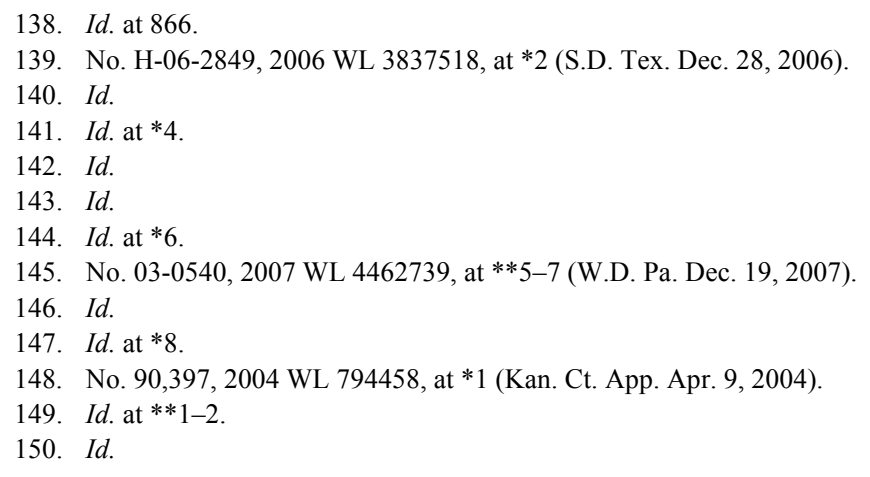




\section{Technology}

The wide use of computer technology in the workplace poses a grave threat to employers' trade secrets, because the trade secrets can be easily and quickly taken and disseminated to others. ${ }^{151}$ Coupled with these technological advances, however, is the decline of loyalty in the workplace discussed above. ${ }^{152}$ Accordingly, the opportunity created by computers combined with the motivation to be unfaithful to an employer has led to the prevalence of employees using technology to misappropriate trade secrets. A sampling of cases over the last four years shows how e-mail, laptops, zip drives, flash drives, and CDs can be hazards to trade secrets, even by those without high-tech training.

It has become a familiar story that employees download, with little effort, large amounts of a company's electronically stored trade secrets onto CDs or flash drives. For instance, in LeJeune v. Coin Acceptors, Inc., an employee who worked from his home and regularly received company documents gained employment with a primary competitor. ${ }^{153}$ Prior to his departure, he transferred digital copies of sensitive information, including budgeting software and pricing information, from his company laptop to a CD. ${ }^{154}$ He then erased the information to hide the downloading activity before he returned the company laptop. ${ }^{155}$ In Anadarko Petroleum Corp. v. Davis, a departing senior engineer downloaded the equivalent of 1.5 million pages of raw text from the company desktop computer to his personal computer. ${ }^{156}$ He used several flash drives to store the information downloaded from the company desktop. ${ }^{157}$ In DuCom v. Georgia, an employee planned to start her own business after she left her employer. ${ }^{158}$ On the day she resigned, she "copied a 'massive' amount of information" from her employer's hard drive onto a disk, including computer software programs and the entire associated business database. ${ }^{159}$

Without attaching any storage devices, employees can simply e-mail trade secrets to themselves and to competitors. In one case, several

\footnotetext{
151. See generally Elizabeth A. Rowe, Contributory Negligence, Technology, and Trade Secrets, 17 Geo. MASON L. ReV. 1 (2009).

152. See generally Stone, supra note 121, at 539-49.

153. 849 A.2d 451, 455-56 (Md. 2004).

154. Id. at 456

155. Id.

156. No. H-06-2849, 2006 WL, at *6 (S.D. Tex. Dec. 28, 2006).

157. Id.

158. 654 S.E.2d 670, 672 (Ga. Ct. App. 2007).

159. Id. at 673 .
} 
employees e-mailed their employer's trade secrets to a competitor for whom they wished to work. ${ }^{160}$ One employee e-mailed numerous business documents belonging to his employer to his personal e-mail account. ${ }^{161}$ He then copied the important materials onto a floppy disk and possibly a $\mathrm{CD}$ and later transferred them to the competitor's computer. ${ }^{162}$ Another employee e-mailed an internal sales document to the competitor, and suggested that the competitor "could use this document to "make [his employers] look like fools with the technical decision makers." "163

Moreover, technology can be used to capture information belonging not only to the employer, but to third parties such as customers. In United States $v$. Zhang, a product development manager gained access to secret product information belonging to a customer of his former employer. ${ }^{164}$ He later accepted new employment with a competitor of that customer. ${ }^{165}$ Prior to his departure, he downloaded dozens of files containing confidential product information. ${ }^{166}$ He then loaded many of the files onto a laptop received from his new employer and e-mailed certain files to his new employer. ${ }^{167}$

Sometimes the very employees trusted with overseeing and implementing the company's technology can use it to misappropriate their employer's trade secrets. In United States v. Sun, an information technology specialist sold his employer's trade secrets for three million dollars. ${ }^{168}$ He delivered a laptop and a hard drive containing stolen trade secrets and confidential proprietary information to the competitor. ${ }^{169}$

\section{THEORETICAL RELATIONSHIP TO EMPLOYEE THEFT}

Sociological theories about employee theft offer useful insights into trade secret misappropriation. While the phrase "employee theft" is not usually used in connection with trade secret misappropriation, the operational definition undoubtedly captures the conduct: "“any unauthorized appropriation of company property by employees either for

160. MicroStrategy, Inc. v. Bus. Objects, S.A., 331 F. Supp. 2d 396, 404 (E.D. Va. 2004).

161. Id. at 407 .

162. Id.

163. Id. at 412 .

164. United States Dep't of Justice, Silicon Valley Engineer Indicted, supra note 112.

165. Id.

166. Id.

167. Id.

168. United States Dep’t of Justice, Illinois Man Pleads Guilty, supra note 115.

169. Id. 
one's own use or for sale to another. It includes, but is not limited to, the removal of products, supplies, materials, funds, data, information, or intellectual property." "170 Accordingly, an understanding of the research in that area might prove useful in examining and devising strategies for trade secret protection. Researchers have developed several theories to explain why people steal from their employers. Equity, work climate, and societal change are three theories that appear to fit well within the context of this paper and are briefly summarized here.

Equity theory suggests that people steal from their employers when they feel a sense of inequity in the workplace. ${ }^{171}$ They are motivated by a need to restore balance where, for instance, they feel underpaid for their efforts. ${ }^{172}$ In addition, when employees feel that they have poor opportunity for advancement or weak job security, it contributes to their sense of inequity and might lead to "compensatory theft." 173 Stealing from the company is thus an attempt to "reestablish equity between the parties involved in a social exchange relationship." 174

Work climate theory suggests that company policies as well as the attitudes of managers and coworkers about employee theft may encourage the behavior. ${ }^{175}$ Where workplace norms condone theft, employees may actually feel the need to support that behavior, ${ }^{176}$ even if they otherwise would have chosen to act ethically. ${ }^{177}$ In one study, thirty-three percent of those surveyed felt pressured to violate company policies by their coworkers and their companies. ${ }^{178}$ Another study revealed that of the eighty percent of people who admitted to regularly stealing from their employers, virtually all of them felt that they had done nothing wrong. ${ }^{179}$

170. Jerald Greenberg, The STEAL Motive, in ANTISOCIAL BEHAVIOR IN ORGANIZATIONS 85, 86 (Robert A. Giacalone \& Jerald Greenberg eds., 1997) (quoting Jerald Greenberg, Employee Theft, in The Blackwell Encyclopedic Dictionary of Organizational BeHavior 154, 154 (N. Nicholson ed., 1995)).

171. Steven H. Appelbaum, Jennifer Cottin, Remy Paré \& Barbara T. Shapiro, Employee Theft: From Behavioural Causation and Prevention to Managerial Detection and Remedies, 9 J. AM. ACAD. Bus. 175, 176 (2006); James Weber, Lance B. Kurke \& David W. Pentico, Why do Employees Steal?, 42 BUS. \& SOC'Y 359, 361-62 (2003).

172. Appelbaum et al., supra note 171, at 176; Greenberg, supra note 170, at 86 .

173. Arthur Gross-Schaefer, Jeff Trigilio, Jamie Negus \& Ceng-Si Ro, Ethics Education in the Workplace: An Effective Tool to Combat Employee Theft, 26 J. BUS. ETHICS 89, 92 (2000).

174. Greenberg, supra note 170, at 94.

175. Appelbaum et al., supra note 171, at 176. See also Greenberg, supra note 170, at 89-90.

176. Greenberg, supra note 170, at 92 .

177. Gross-Schaefer et al., supra note 173 , at 92

178. Appelbaum et al., supra note 171, at 176.

179. Id. 
Societal change theory suggests that ethical behavior is learned at home, taught by parents to their young children. ${ }^{180}$ This theory posits that the degradation of the family structure along with other societal influences has led to a "moral laxity" in children before they enter the work force. ${ }^{181}$ The focus is now on maximizing one's self-interest, ${ }^{182}$ thus supporting questionable workplace ethics such as theft. ${ }^{183}$

Since trade secret misappropriation is a kind of theft, these theories seem applicable to trade secret protection. The motivation to misappropriate may be very similar to that which encourages one to steal any other type of property which belongs to the employer. Accordingly, what follows is an initial attempt to introduce possible connections between sociological employee theft theories and trade secret law using New Generation Employees as the medium. However, the theories can also be applied more broadly using, for example, all employees or other patterns and trends in trade secret misappropriation. The attitudes and behaviors of New Generation Employees, however, seem particularly fitting.

\section{A. Application to New Generation Employees and Trade Secrets}

Having introduced three general theories on employee theft, this section now integrates the attitudes and behaviors of New Generation Employees with these sociological theories in a framework that (a) offers some explanations about what motivates employees to misappropriate trade secrets and (b) offers corresponding general preventive measures to protect trade secrets in the workplace. No single theory offers a superior explanation for trade secret misappropriation. Instead, there is a good deal of overlap among the theories. Thus, it is the overall combination of these theories that might prove most useful to trade secret law.

\section{Equity Theory: "How Do You Make Me Feel?"}

New Generation Employees possess many attitudes that suggest they are likely to feel a sense of inequity in the workplace. First, weak job security means that they cannot trust companies to take care of them so they must take care of themselves. ${ }^{184}$ Second, as a result of not trusting

\footnotetext{
180. Id.

181. Gross-Schaefer et al., supra note 173, at 92.

182. Id.

183. Appelbaum et al., supra note 171, at 176.

184. See TUlgan \& MARTIN, supra note 51, at 19-20; O'Bannon, supra note 4, at 95-96.
} 
that long term rewards will come to fruition, they want it all today and want to be rewarded today. ${ }^{185}$ Incentives, feedback, and rewards are very important, ${ }^{186}$ and, when not received, can lead to resentment. ${ }^{187}$ Third, they want to feel valued by managers and do not respond well to a "do-it because I said so" management style. ${ }^{188}$ Fourth, they are very interested in career advancement and expect to be given opportunities to do so. ${ }^{189}$ They "will sidestep rules and procedures that slow them down as they push for results." 190

As applied to trade secret law, this theory seems apt for assessing how employees feel relative to their expectations. When they feel undercompensated, undervalued, and underappreciated, they are likely to also feel resentful, and maybe even revengeful, toward the company that is perceived to be taking advantage of them. Thus, taken together, this creates circumstances where New Generation Employees could feel a need to restore balance to an inequitable situation. To compensate for that perceived inequity, they may take or use the employer's trade secrets in a way that might further their own advancement or add to their value to other employers. This is a familiar story line in many trade secret cases.

Recall, for instance, that in Anadarko Petroleum Corp. v. Davis, an engineer became dissatisfied, and felt that he had been passed over for promotions and "pushed to the side." supervisors were making "poor decisions." 192 As a result, he left with trade secrets to join a competitor. ${ }^{193}$ Also, in Lexis-Nexis v. Beer, an employee who was dissatisfied with his compensation resigned and accepted employment with a competitor, but not without taking the former employer's customer information database with him. ${ }^{194}$

\section{Work Climate Theory: "Everyone Else Is Doing It"}

Workplace norms may unwittingly support trade secret misappropriation not only by the indirect messages that the company

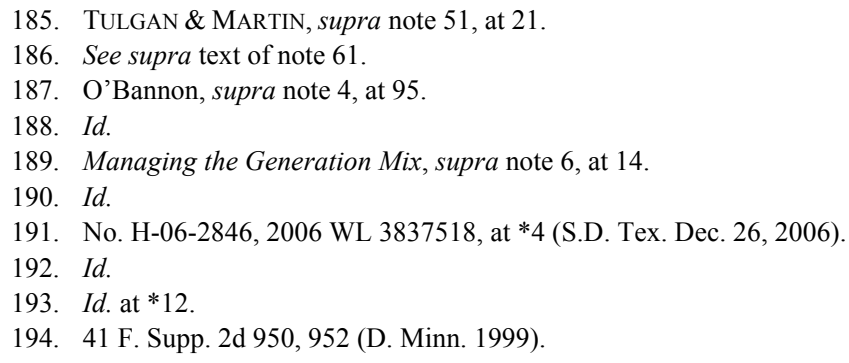


sends to its employees, but also by what the employees perceive to be acceptable behavior based on their peers' actions. "Individuals enter an organization with preconceived notions of what 'ought' and what 'ought not' be. As a result, values cloud objectivity and rationality and generally influence attitudes and behavior." 195 With that in mind, New Generation Employees' attitudes about changing jobs as well as their allegiance to their coworkers could be problematic for trade secret owners.

Job-hopping is a normal, accepted method of career advancement for this group. ${ }^{196}$ That mobility threatens trade secrets insofar as employees are likely to use a former employer's trade secrets to increase their value to a new employer. Indeed, they may see nothing wrong in doing so, perhaps believing that they are entitled to use information which they helped create or that the information is part of their professional tool kit. The fact that New Generation Employees are so proficient and familiar with technology, coupled with the ease with which trade secrets can be emailed or downloaded, may even encourage misappropriation and reduce the guilt or stigma associated with that conduct. ${ }^{197}$

New Generation Employees value creating relationships in the workplace, and may feel stronger connections to coworkers than they do to the company itself. ${ }^{198}$ Indeed, recall that Gen Yers "will choose a job just to be with their friends." 199 This suggests that a kind of "pack mentality" could develop where employees excuse, and perhaps even assist, ${ }^{200}$ their coworkers who see taking trade secrets as an acceptable way to advance one's career. They may also be less likely to report any misappropriation to the company, deeming it more appropriate to protect a coworker than to assist an employer to whom they feel very little loyalty. From the trade secret owner's perspective, this may emphasize the need to take action against misappropriators in order to raise awareness among employees about the risks of trade secret misappropriation, and to emphasize that the company takes protection of its secrets seriously.

\footnotetext{
195. O'Bannon, supra note 4, at 100-01.

196. Bova \& Kroth, supra note 7, at 57.

197. See supra Part IV.C.

198. See Jones, supra note 64.

199. Trunk, supra note 5.

200. In Intellisports LLC v. Fitzgerald, for example, a departing editor who started a competing business received assistance from a former coworker to obtain the former employer's confidential customer list to solicit customers for his new venture. No. 90,397 2004 WL 794459, at**1-2 (Kan. Ct. App. Apr. 9, 2004).
} 
More broadly, application of this theory is also consistent with criminal causation theory - the view that criminal conduct is a rational choice derived through cost-benefit analysis. ${ }^{201}$ My underlying assumption for this rational choice analysis is that most potential trade secret misappropriators are otherwise law-abiding citizens who conform to the law, but who misappropriate an employer's trade secrets because the opportunity presents itself, or because he or she has justified it as "not wrong." Thus, under this view, employees will misappropriate trade secrets when the benefits outweigh the costs of doing so.

The potential benefits associated with trade secret misappropriation include career advancement, financial gain, improved social status, and revenge against an employer. The potential costs can be roughly grouped into two categories for ease of labeling: primarily economic and primarily social. The primarily economic costs include, for example, the expense, time, and stress associated with defending a misappropriation action, loss of employment and its attendant financial loss, and possible criminal or civil sanctions or both.

Among the social costs most relevant to New Generation Employees is the loss related to violation of social norms. ${ }^{202}$ These norms establish behaviors that are socially acceptable and those that are not. ${ }^{203}$ When one violates a social norm he risks losing social acceptance and status, ${ }^{204}$ and thus, societal (or group) reaction to the behavior serves as a deterrent. As applied to New Generation Employees, the above discussion suggests that their workplace norms, as expressed by their attitudes and behaviors, may support trade secret misappropriation rather than discourage it. Taken together, their lack of loyalty to employers, affinity for job hopping, strong connections to coworkers, and entrepreneurial zeal may contribute to the view that one who is accused of trade secret misappropriation by an employer has not really done anything wrong or is being unfairly treated by the employer. Ultimately, this perceived reaction serves not as a deterrent, but as support for the

201. See Derek B. Cornish \& Ronald V. Clarke, Understanding Crime Displacement: An Application of Rational Choice Theory, in THE CRIMINOLOGY THEORY READER 45, 46 (Stuart Henry \& Werner Einstadter eds., 1998) ("Rational choice theory assumes that offenders respond selectively to characteristics of particular offenses - to their opportunities, costs, and benefits-in deciding whether or not to offend.")

202. See Paul H. Robinson, Why Does the Criminal Law Care What the Layperson Thinks Is Just? Coercive Versus Normative Crime Control, 86 VA. L. REV. 1839, 1862 (2000) (describing how social norms can deter crime).

203. See Richard A. Cloward \& Lloyd E. Ohlin, Delinquency and Opportunity, reprinted in Classics OF CRIMINOLOGY 171, 171 (Joseph E. Jacoby ed., 1979) (1960) ("[N]orms that define legitimate practices also implicitly define illegitimate practices.").

204. See id. (discussing costs of committing crime other than arrest). 
behavior. A similar development has occurred in copyright law, where strong social norms among Gen Yers have led to large-scale difficulties for copyright owners who wish to restrict online file sharing of music. ${ }^{205}$ Surveys of these individuals reveal their lack of concern about copyright laws and their belief that their behavior is acceptable because it causes no harm. $^{206}$

With respect to trade secret law, integrating a rational choice approach with a work climate theory illustrates the importance of workplace behavior and the attendant norms which are established. If, as this Article suggests, New Generation Employees comprise the largest segment of the workforce today, then the norms to which they subscribe could potentially have a significant effect on the prevalence and detection of trade secret misappropriation. In short, their attitudes as a group could influence individual decisions about misappropriation. When faced with a choice - such as, should I download these secret files to take to my new job? - if the benefits of misappropriating are apparent and the perception is that "everyone else is doing it," then the scale tips toward engaging in the unlawful conduct. It also means that the primarily economic costs, such as the perceived likelihood of being caught, sued, prosecuted, and sanctioned, must be made very clear in order for one to make a rational choice that the overall costs outweigh any benefits from misappropriation.

\section{Societal Change Theory: "Looking out for Number One"}

A trait that is repeatedly associated with New Generation Employees is self-interest. Gen Yers, in particular, have been pointedly called an "overindulged, spoiled, and disengaged group that looks at the world through a prism of self interest." 207 Social change theorists might associate that attitude with a degradation of the family structure, which resulted in inadequate moral and ethical instruction at home. While Gen Xers might support that family-life hypothesis, Gen Yers do not.

Some believe that Gen Xers were "[t]he most unsupervised generation." ${ }^{208}$ As noted earlier, they were latchkey kids, with television as a babysitter, and grew up with divorced parents or in homes where

205. See John Palfrey \& Urs Gasser, Born Digital: Understanding the First GENERATION OF Digital NATIVES 138 (2008) (discussing research on the lack of regard for copyright laws by young people who download and share music).

206. Id.

207. Gogoi, supra note 9.

208. Managing the Generation Mix, supra note 6, at 12. 
both parents worked. ${ }^{209}$ They did not develop strong connections to social institutions such as churches. ${ }^{210}$ They came of age at a time when they were surrounded by stories of missing children, AIDS, sexual abuse, and police brutality. ${ }^{211}$ As a result, Gen Xers had to learn at an early age to fend for themselves and learned to be resourceful and independent along the way. ${ }^{212}$ Gen Yers experience with family, on the other hand, was different.

Thus, it seems more appropriate to associate the self-interest of both Gen Xers and Gen Yers to the aforementioned societal factors, both familial and economic, that shaped their consciousness and values, rather than focus on ethical or moral upbringing. These factors appear to have fostered greater independence and entrepreneurism in the New Generation Employees. Accordingly, their being very entrepreneurial and viewing themselves "more as independent contractors rather than employees" 213 could have serious implications for trade secret protection. Their self-interest is also consistent with their general lack of loyalty to companies and with the theories described above, Equity and Work Climate.

Self-interest is highly incompatible with trade secret protection to the extent that it encourages workers to care less about protecting the employer's trade secrets and more about advancing their own careers. Indeed, research has demonstrated that "a climate focused on self-interest not only appears to promote unethical conduct, it also has a negative influence on organizational commitment." ${ }^{\text {"214 }}$ Several of the cases discussed earlier serve to illustrate how employees' self-interest, especially when combined with competitive entrepreneurial aspirations, can lead to trade secret misappropriation. For instance, in Hilb, Rogal \& Hamilton Co. of Atlanta v. Holley, after an insurance agent merged his agency with another company and became dissatisfied with the vision and focus of the newly merged company, ${ }^{215}$ he left, taking clients and

209. Kupperschmidt, supra note 18 , at 38 .

210. Managing the Generation Mix, supra note 6, at 12.

211. Id.

212. Id.

213. O'Bannon, supra note 4, at 100. See also Armour, supra note 7 (“'Change, change, change. Generation Yers don't expect to stay in a job, or even a career for too long...."); Managing the Generation Mix, supra note 6, at 17 ("According to Gen Y, 'job security' means, 'I'll learn all I can here and, as soon as opportunities to keep on learning disappear, I'll look for a better position with another organization. Of course, I'll negotiate the best deals for my expanded skills, experiences, and knowledge."').

214. Linda Klebe Treviño, Kenneth D. Butterfield \& Donald L. McCabe, The Ethical Context in Organizations: Influences on Employee Attitudes and Behaviors, 8 Bus. ETHICS Q. 447, 470 (1998).

215. 644 S.E.2d 862, 864-65 (Ga. Ct. App. 2007). 
their confidential information to his new employer. ${ }^{216}$ In Latuszewski v. Valic Financial Advisors, Inc., several financial advisors, while still employed, formed their own competing business venture. ${ }^{217}$ They then left, and, using trade secrets, transferred ten million dollars in assets from the former employer. ${ }^{218}$ Similarly, in DuCom v. Georgia, an employee planning to start her own business copied and took a large amount of trade secret information to aid in her venture. ${ }^{219}$

\section{B. Lessons in Prevention}

Employee theft theories have provided guidance to researchers in suggesting various prevention measures against theft. ${ }^{220}$ Some of those measures that seem more applicable to trade secret protection include: (a) changing corporate culture, (b) instituting internal controls, (c) punishing employees who steal, and (d) performing screening tests (including integrity tests). ${ }^{221}$ These measures may be interrelated and could be used together in a manner that best fits the particular company and the nature of its employees.

A corporate culture that includes a focus on honesty and the benefits of and respect for intellectual property, including trade secrets, could reinforce to all workers, both management and non-management personnel, the importance of intellectual property protection and the consequences for misappropriation. Research has demonstrated that when the work environment is egotistic or based on self-interest, employees are more likely to engage in unethical behavior. ${ }^{222}$ Thus, to the extent a large portion of the employees are New Generation Employees, this could help influence their mindset about trade secret ownership, promoting values that focus less on self-interest and competitive goals, and more on the consequences of misappropriation. ${ }^{223}$

The use of internal controls to track money and other kinds of business property often includes accounting controls, security systems, and centralization of processes to allow tighter controls. ${ }^{224}$ Similarly,

\footnotetext{
216. Id. at 865 .

217. No. 03-0540, 2007 WL 4462739, at**5-7 (W.D. Pa. Dec. 19, 2007).

218. $I d$. at $* 8$.

219. 654 S.E.2d 670, 672 (Ga. Ct. App. 2007).

220. See Appelbaum et al., supra note 171, at 176.

221. See id. at 176-78.

222. See Weber et al., supra note 171 , at 365 .

223. See id. (noting that a "work climate, based on universal ethical principles such as honesty, justice, and fairness, would support ethical actions by employees").

224. Appelbaum et al., supra note 171, at 177.
} 
appropriate systems should be implemented to control and track trade secrets, and companies should perform risk assessments to develop affirmative and concrete steps to protect trade secrets. Internal controls relating to computers and other electronics, where trade secrets could be particularly vulnerable, might also be beneficial. ${ }^{225}$

Punishment has a deterrent effect on other employees who might want to steal from an employer. ${ }^{226}$ Moreover, when punishment is inconsistent or unseen, it might have the opposite effect and encourage theft. ${ }^{227}$ Punishment for trade secret misappropriation generally involves two steps: first, termination from employment (frequently, however, the misappropriation is not discovered until the employee has left the company), and second, litigation against the employee, and possibly the new employer, for trade secret misappropriation. Taking such steps is consistent with the above theories about punishment, and helps to send a message to remaining employees and to the new employer that such conduct will not be tolerated. ${ }^{228}$ It is also a highly visible way to raise awareness among employees about the risks of trade secret misappropriation, and to emphasize that the company takes protection of its secrets seriously.

The screening out of potential hires that might be most likely to steal trade secrets is intriguing. Indeed, there is a new measurement tool called an integrity test that purports to identify individuals' attitudes towards a variety of unacceptable behaviors, including stealing. ${ }^{22}$ Some researchers believe that integrity tests are a reliable and valid tool to determine who is likely to steal or display hostile tendencies. ${ }^{230}$ Others, however, question the validity of the tests. ${ }^{231}$

Whether integrity tests will be a good predictor for trade secret theft is left to be seen. However, this kind of test, in combination with appropriate information gathering about prospective employees - such as the reason for leaving their previous employment or even their offering

225. For a detailed discussion of the risks posed to trade secrets by the use of technology, see Rowe, supra note 151.

226. Appelbaum et al., supra note 171, at 177 .

227. Id.

228. See PoOLEY, supra note $89, \S 10.01[1]$ ("The former employer wants to teach a lesson to those who have wronged him, and discovers that lawsuits are an effective way to cause excruciating pain to the start-up enterprise.").

229. Appelbaum et al., supra note 171, at 177.

230. Id.

231. See, e.g., Cornelius J. König et al., The Relationship Between the Ability to Identify Evaluation Criteria and Integrity Test Scores, 48 PsychOL. SCI. 369, 374-76 (2006); Annie Murphy Paul, The Cult of Personality Tests: A Flawed but Trendy Management Tool, Boston GLOBE, Feb. 13,2005 , at F12. 
to use their previous employer's trade secrets in their new positioncould be a useful predictive tool. It is worth a note of caution, however, that screening out broad classes of people is not advisable. For instance, a decision not to hire men because they tend to engage in more unethical behavior than women, ${ }^{232}$ not only eliminates a large portion of potential hire, but it could also subject an employer to liability.

\section{DOCTRINAL IMPLICATIONS}

While the foregoing theories may help explain New Generation Employees' motivation to misappropriate trade secrets, it is also important to look beyond motivation and explore the possible doctrinal implications of having employees whose attitudes and behaviors could so challenge the existing paradigm of trade secret protection. The more direct effect on trade secret law will likely be an increase in trade secret misappropriation litigation, because New Generation Employees' values appear incompatible with trade secret protection. In addition, over time, any new trends in the workplace associated with New Generation Employees - such as the wide use of technology - might call for a reevaluation of some of the doctrinal standards and theories that may be applied to misappropriation. ${ }^{233}$

Existing legal frameworks in trade secret law are capable of addressing the kinds of legal issues that may arise in cases involving New Generation Employees. For instance, it is settled that regardless of motivation, misuse of an employer's trade secrets is actionable. However, plaintiff trade secret owners face difficulty because they carry the legal burden of proving trade secret misappropriation, and New Generation Employees could potentially present serious threats to their ability to do so.

This Article identifies three areas where one should expect New Generation Employees' attitudes and behaviors to influence doctrinal arguments that may be framed in defense of trade secret misappropriation claims. These relate to the definitions of misappropriation, ownership challenges, and liability of new employers based on departing employees' misappropriations. The overall

232. See Weber et al., supra note 171 at 367-68 ("[M]ost empirical business ethics studies find women to be more ethical in their decision making than men.").

233. For example, in a separate paper, I explore whether courts should change the way they apply the standard requiring trade secret owners to take "reasonable efforts" to protect trade secrets in light of the wide use of technology in the workplace to store and transmit trade secrets. See Rowe, supra note 151. 
implication is that employers should be particularly mindful and cautious about the workplace environment and culture, as the behavior of New Generation Employees could make enforcement of trade secret rights that much more difficult.

\section{A. Is It Misappropriation If I Didn't Think I Was Stealing?}

When an alleged misappropriator sets off to pursue his entrepreneurial aspirations or to join a competitor, a plaintiff employer may cast him as self-interested, disloyal, and revengeful. The defendant, who may have thought of himself more as an independent contractor than as an employee, might not understand why his conduct could meet the definition of trade secret misappropriation. However, trade secret law is the branch of intellectual property law that most closely regulates standards of commercial ethics, guides the morality of the business world, and underscores fair dealing. ${ }^{234}$ Consistent with these underlying ethical and equitable approaches, all of the statutory frameworks of trade secret law prohibit the use of improper means to acquire trade secrets. ${ }^{235}$

Under both the Restatement (First) of Torts and the modern codifications of trade secret law, one need not have intended to steal a trade secret to be liable for misappropriation. ${ }^{236}$ Rather, the use of improper means to procure another's trade secret forms the basis for liability. ${ }^{237}$ Accordingly, it is the breach of one's duty of good faith through "breach of contract, abuse of confidence, or impropriety in the method of ascertaining the [trade] secret" that makes it misappropriation under the Restatement. ${ }^{238}$ "Improper means" under the UTSA includes "theft, bribery, misrepresentation, breach or inducement of a breach of a duty to maintain secrecy, or espionage through electronic or other

234. See, e.g., Kewanee Oil Co. v. Bicron Corp., 416 U.S. 470, 481-82 (1974) ("The maintenance of standards of commercial ethics and the encouragement of invention are the broadly stated policies behind trade secret law."); RESTATEMENT (THIRD) OF UNFAIR COMPETITION § 39 cmt. a (1995) ("The imposition of liability for the appropriation of a trade secret protects the plaintiff from unfair competition and deprives the defendant of unjust enrichment attributable to bad faith.").

235. UNIF. TRAde SeCrets ACt $\S 1$ (amended 1985), 14 U.L.A. 537 (2005); Restatement (THIRD) OF UNFAIR COMPETITION $§ 40$ (1995); RESTATEMENT (FIRST) OF TORTS $§ 757 \mathrm{cmt}$. a (1939).

236. See UnIf. Trade Secrets Act $\S 1(2)$; Restatement (FIrST) OF TorTs $§ 757 \mathrm{cmt}$. a (1939). Note that the Economic Espionage Act requires that the defendant knowingly stole or otherwise obtained the trade secret information in order for federal criminal liability to attach. 18 U.S.C. $\S 1832(2006)$

237. See Unif. § 1832; Trade Secrets Act § 1(2); Restatement (First) OF TORTS $§ 757$ cmt. a (1939).

238. RESTATEMENT (FIRST) OF TORTS $§ 757 \mathrm{cmt}$ a (1939). 
means."239 Thus, any unauthorized taking, transferring, or use of a secret is misappropriation under the UTSA. ${ }^{240}$

Despite the use of the words "theft" and "stealing" when discussing trade secret misappropriation, the underlying construct of trade secret law does not view trade secrets as property, but rather grounds trade secret protection on a general duty of good faith. ${ }^{241}$ Thus, the presence of a confidential relationship or good faith obligation is a necessary prerequisite, and it is that breach that triggers something akin to an enforceable property right in the trade secret. ${ }^{242}$ This creates a potential pitfall for employers dealing with New Generation Employees, because it becomes imperative that the employer establish the requisite confidential relationship with employees, and place them on notice about what information it claims as a trade secret. Otherwise, a workplace norm wherein the employees' attitudes and behaviors are incompatible with recognition and protection of trade secrets, coupled with an employer which has not taken affirmative steps to educate and establish the necessary expectation of confidence, could strengthen a defendant's argument against misappropriation.

One available legal tool for establishing direct evidence of a confidential relationship is through the use of restrictive covenants. Restrictive covenants enhance an employer's legitimate interests in its trade secrets and other assets, such as goodwill. Courts recognize the employer's need for such covenants to encourage investment, protect innovation, and promote free competition. ${ }^{243}$

As a condition of employment, employers could require that employees sign agreements acknowledging that the employment creates a relationship of confidence and trust with respect to confidential information. These nondisclosure or confidentiality agreements express in writing the common law obligation of an employee to maintain the confidential nature of the employer-employee relationship. In later

239. UNIF. TRADE SECRETS ACT § 1(1).

240. See id. §1(2).

241. See RESTATEMENT (FIRST) OF TORTS $\S 757 \mathrm{cmt}$ a (1939).

242. See Lockridge v. Tweco Prods., Inc., 497 P.2d 131, 136 (Kan. 1972) (discussing why the misappropriation of a trade secret is not a continuing wrong).

243. See, e.g., Ticor Title Ins. Co. v. Cohen, No. 98 Civ. 4001 (JSM), 1998 WL 355420, at *4 (S.D.N.Y. July 2, 1998), aff'd, 159 F.3d 774 (2d Cir. 1998) ("There is nothing unfair in holding Mr. Cohen to be bound to the contract term that he accepted in return for highly lucrative employment. The non-compete served to protect legitimate business interests.... [I]t is also appropriate to enforce the non-compete clause here in order to protect trade secrets and confidential information."); Applied Micro, Inc. v. SJI Fulfillment Inc., 941 F. Supp. 750, 757-58 (N.D. Ill. 1996) (finding "[t]he purpose of the non-compete was not simply to restrain trade, but rather to protect AMI's customer base," and, therefore, the covenant was enforceable under Illinois law). 
litigation, these agreements could serve the evidentiary purpose of (1) delineating the confidentiality expectations between the employer and the employee, (2) showing that the employer takes trade secret protection seriously, and (3) demonstrating the employer's reasonable efforts to maintain the secrecy of its confidential information. ${ }^{244}$

While there is generally little or no hesitation to signing a nondisclosure agreement, another kind of restrictive covenant, the noncompetition agreement, may be more difficult to obtain from employees. This may be especially challenging with New Generation Employees who treasure their mobility and may be loathe to sign any agreements that restrict their employment prospects. By entering into a noncompetition agreement, the employee usually agrees that for a specified period of time after the end of her employment, she will not work for any company that is a competitor of the employer. The validity of noncompetition agreements is governed by state law. Many states recognize and enforce noncompetition agreements as long as the restrictions are reasonable in view of the totality of the circumstances, including the scope of geographical, temporal, and competitive activity restrictions. $^{245}$ Some states prohibit the use of noncompetition agreements entirely. ${ }^{246}$

\section{B. Isn't It Mine If I Worked on It?}

One of the most frequently litigated issues in trade secret misappropriation cases is ownership of the trade secret. Because New Generation Employees, upon leaving a company, may believe they are entitled to use information on which they worked or information that is part of their professional tool kit, more conflicts related to ownership may arise. The general rule is that a former employee may use the general knowledge, skills, and experience acquired during her employment, even in competition with her former employer. ${ }^{247}$ However, the former employee may not use the confidential or trade

\footnotetext{
244. See, e.g., Stephen L. Sheinfeld \& Mark A. Konkel, Protecting Employer Secrets and the "Doctrine of Inevitable Disclosure", in HANDLING Wrongful TERMination Claims 2001: What PlainTIFFS AND DEFENDANTS HAVE TO KNOW 411, 443-44 (2001).

245. See, e.g., Inflight Newspapers, Inc. v. Magazines In-Flight, LLC, 990 F. Supp. 119, 135-40 (E.D.N.Y 1997) (enforcing one year restriction); Habif, Arogeti \& Wynne, P.C. v. Baggett, 498 S.E.2d 346, 354-55 (Ga. Ct. App. 1998) (enforcing two year restriction).

246. See, e.g., CAl. Bus. \& Prof. Code § 16600 (West 2008); Colo. Rev. Stat. § 8-2-113(2) (West 2003); OKLA. STAT. ANN. tit. 15, § 217 (West Supp. 2009).

247. RESTATEMENT (THIRD) OF UNFAir COMPETITION $\S 42 \mathrm{cmt} . \mathrm{d}$ (1995).
} 
secret information of the former employer. ${ }^{248}$ This principle promotes, among other things, the public interest in labor mobility and in fair and vigorous business competition. ${ }^{249}$

Because the issue of ownership is affected by public policy, and to some extent, the personal philosophies of the judge or jury, New Generation Employees as a group could influence the application of these ownership principles. It is often difficult to separate that which belongs in an employee's professional tool kit from that which is an employer's protectable trade secret. Therefore, the factors in each case must be carefully weighed to determine whether they favor protection or not. Accordingly, when New Generation Employees establish new workplace norms - for example, higher technical skills, higher levels of education, and higher rates of job-hopping for career advancement-it is possible that we could move toward a more expansive view of one's "general skill or knowledge," thus restricting the information that can be protected as a trade secret. Where "information is so closely integrated with the employee's overall employment experience that protection would deprive the employee of the ability to obtain employment commensurate with the employee's general qualifications, it will ordinarily not be protected as a trade secret . . ..,250

New Generation Employees' ambitions and innovative spirit may also lead to questions about who owns trade secrets on which the employee may have worked or helped create. Generally, if an employee's job duties (interpreted broadly) involved the development or collection of the material, then it belongs to the employer. ${ }^{251}$ Similarly, if the disputed information is an invention, and the invention results from work performed by the employee within the scope of her duties, then the employer owns it. ${ }^{252}$ The rule applies even if the invention was derived from the employee's skill and knowledge, ${ }^{253}$ and even if one claims she was an independent contractor rather than an employee. ${ }^{254}$

New Generation Employees are likely to argue that material may have been developed on their own time. Recall, for instance, one Gen-

248. Id. § 42 cmts. b-c

249. See CVD, Inc. v. Raytheon Co., 769 F.2d 842, 852 (1st Cir. 1985); Fleming Sales Co. v. Bailey, 611 F. Supp. 507, 514 (N.D. Ill. 1985).

250. Restatement (ThiRD) OF UNFAIR COMPETITION $\S 42 \mathrm{cmt}$. d (1995).

251. See, e.g., Northern Elec. Co. v. Torma, 819 N.E.2d 417, 422 (Ind. Ct. App. 2004).

252. RESTATEMENT (THIRD) OF UNFAIR COMPETITION $\S 42 \mathrm{cmt}$. e (1995).

253. Id.

254. See, e.g., Computer Assocs. Int'l, Inc. v. Am. Fundware, Inc., 831 F. Supp. 1516, 1524 (D. Colo. 1993) ("Although status as an employee or independent contractor is relevant to the ownership of a copyright, it is irrelevant to the ownership of a trade secret."). 
Y-consultant's comment that the new work-week model was "work 60 hours a week, devote 20 hours to nonprofit, and spend 20 hours writing a plan to start your own business." 255 If the employer's trade secrets were used without authorization to develop the new business plan, then the employee may be liable for misappropriation. Moreover, if the employee used the employer's resources to develop his creation, the employer may have a royalty-free license to use the invention, known as a "shop right." 256 Even when an employee owns an invention, her use of it may be restricted while she remains with her employer. ${ }^{257}$ That is because employees must at all times conduct themselves in a manner that is consistent with their duty of loyalty to the employer. ${ }^{258}$

Because these various common law doctrines regarding ownership can be vague and nuanced, the simplest way to allocate ownership rights is by contract. Employers typically require employees to sign contracts agreeing to assign all inventions designed or conceived during the period of employment to the employer. ${ }^{259}$ Therefore, given the propensities of New Generation Employees, it would be wise for employers to be particularly conscientious about explicitly setting out the expectations about ownership in contracts. These highly mobile and entrepreneurial employees, however, may view such agreements as anticompetitive and unfair. ${ }^{260}$ Therefore, to be enforceable, the contracts should be drafted so as not to unreasonably impede employees' ability to pursue their careers.

\section{Is My New Employer Liable Too?}

When job hoppers hop to a new job and are accused of taking or using their former employer's trade secrets, the new employer (in addition to the employee herself) may also be liable under trade secret law. ${ }^{261}$ While competing companies are free to solicit and hire each

255. See Gogoi, supra note 9.

256. See Restatement (ThiRd) OF UNFAir COMPETITION $\S 42 \mathrm{cmt}$. e (1995).

257. See Avtec Sys., Inc. v. Peiffer, 805 F. Supp. 1312, 1319-20 (E.D. Va. 1992), aff'd in part, vacated in part, 21 F.3d 568 (4th Cir. 1994) (finding that an employer may acquire a trade secret in a "program's use for demonstration and marketing purposes in a similar manner as an employer may possess 'shop rights' to an employee's patented invention")

258. See id. at 1321.

259. See, e.g., Ingersoll-Rand Co. v. Ciavatta, 542 A.2d 879, 886 (N.J. 1988).

260. Recognizing that employers often have the superior bargaining position, some states have enacted "garage inventor" statutes which are intended to protect employees from unfair restriction of their rights. See, e.g., CAL. LAB. CODE $§ 2870$ (West 2003); Ill. Comp. Stat. AnN., 765/1060-1 (West 2001); Minn. Stat. AnN. § 181.78 (West 2006); N.C. Gen. Stat. AnN. § 66-57.1 (West 2000); WASH. REV. CODE ANN. $\$ 49.44 .140$ (West 2008).

261. See, e.g., Telex Corp. v. Int'l Bus. Mach. Corp., 367 F. Supp. 258, 359 (N.D. Okla. 1973), 
other's employees (unless a noncompetition agreement proscribes it), hiring a former employee of a company in order to gain access to the former employer's trade secrets is called "raiding" and is actionable under trade secret law. ${ }^{262}$ Given that New Generation Employees' tend to develop strong relationships with their coworkers and may "choose a job just to be with their friends, ${ }^{, 263}$ mass departures or hiring a group of coworkers may lead to an increase in raiding claims over the next few years. Raiding claims appear stronger when they involve the hiring away of a group of employees, or of key employees. ${ }^{264}$ The new employers will be forced to defend against these allegations by putting forth evidence that the employees, for instance, were unhappy and looking to change jobs, and that they were hired through the normal process and not targeted. ${ }^{265}$

Furthermore, while New Generation Employees may switch jobs as a means to advance their careers and obtain higher salaries, employers who offer unusually high compensations to former employees of a competitor could create an inference that the employer is paying for access to the former employer's trade secrets, and not the employee's talents. ${ }^{266}$ Thus, hiring someone who has been exposed to a competitor's trade secrets can be risky and could subject the new employer to trade secret misappropriation claims as well. Since it is logical that a company would want to hire those employees who already have experience in the field or industry, companies must nonetheless anticipate that these employees would have had exposure to a competitor's trade secrets and thus take steps to avoid disclosure or use of those secrets. Willful blindness will not protect the new employer. ${ }^{267}$

aff'd in part, 510 F.2d 894 (10th Cir. 1975).

262. Universal Analytics, Inc. v. MacNeal-Schwendler Corp., 707 F. Supp. 1170, 1176 (C.D. Cal. 1989).

263. Trunk, supra note 5.

264. See Telex Corp., 510 F.2d at 910; Sperry Rand Corp. v. Rothlein, 241 F. Supp. 549, 55859, 565 (D. Conn. 1964) ("A balancing of considerations is likewise called for in passing upon the propriety of the defendants' behavior in inducing a mass departure of Sperry employees, skilled and trained in the Sperry process, to take up employment with the defendant's company.").

265. See, e.g., Universal Analytics, Inc., 707 F. Supp. at 1176.

266. See, e.g., In re Innovative Constructive Sys., Inc., 793 F.2d 875, 878 (7th Cir. 1986) (employee paid forty percent more); Rohm and Haas Co. v. Adco Chemical Co., 689 F.2d 424, 428 n.3 (3d. Cir. 1982) (employee paid twenty-five percent more than paid by previous employer ).

267. See First Health Group Corp. v. Nat'1 Prescription Adm'rs, Inc., 155 F. Supp. 2d 194, $227-$ 28 (M.D. Pa. 2001); Rohm and Haas Co., 689 F.2d at 431. 


\section{VII.BENEFITS BEYOND THE WORKPLACE AND TRADE SECRETS}

Whether or not one accepts wholesale the generational labels given to these New Generation Employees or the characteristics that have been ascribed to them, ${ }^{268}$ there is value in being mindful of how the human element effects compliance with workplace laws and policies. At the very least, it helps to ensure that the organization and employees understand each other. The organization's rule may read "do not steal," but to be effective, the employees must understand what it means to "steal."

As employers learn more about these New Generation Employees and attempt to make changes in the workplace to accommodate their expectations and values, ${ }^{269}$ it is also important to consider how the attitudes of these New Generation Employees might affect intellectual property protection. At a minimum, for instance, companies should understand that New Generation Employees cannot be expected to follow policies and procedures regarding intellectual property unless they understand why those policies are in place. ${ }^{270}$ They will not simply do as they are told. ${ }^{271}$ Understanding these generational differences is vital to the process of discovering the most effective methods to teach the kinds of values that are necessary for successful trade secret protection and the efficient operation of the business more generally. ${ }^{272}$ The alternative might be not only a dysfunctional workplace "fraught with miscommunication, misunderstanding and harsh feelings," 273 but the loss of trade secrets and more trade secret misappropriation litigation. Even looking beyond the workplace and beyond trade secrets, it is beneficial to recognizing and acknowledging the challenges that arise when humans meet intellectual property.

268. See Erin White, Age is as Age Does: Making the Generational Gap Work for You, WALL ST. J., June 20, 2008, at B6 (noting that Peter Cappelli of the University of Pennsylvania's Wharton School of Business contends that some consultants confuse age attributes with generational attributes).

269. Companies are finding it difficult to retain Gen Yers and have instituted a wide range of efforts to attract and keep them happy. For instance, Aflac offers flexible work schedules, more recognition, and time off to award good employees. Armour, supra note 7. Xerox has adopted the slogan "Express Yourself" to appeal to Gen Yers' desire for change and independent thinking. Id. Deloitte has a person in charge of recruiting and retaining Gen Yers, and Sun Microsystems has instituted a telecommuting program. Trunk, supra note 5.

270. See Bova \& Kroth, supra note 7, at 59; Managing the Generation Mix, supra note 6, at 15.

271. Managing the Generation Mix, supra note 6, at 15.

272. See Bova \& Kroth, supra note 7, at 57.

273. O'Bannon, supra note 4, at 97. 


\section{A. Effect on Intellectual Property Generally}

The sociological approach used in this Article, which considers the interplay between human values and legal doctrine may have broader usefulness to intellectual property protection generally. "[V]alues are important to the study of organizational behavior, because they lay the foundation for the understanding of attitudes and motivation, and because they influence our perceptions."274 Thus, changes in attitude about intellectual property in general might have implications for innovation, protection, compliance, and enforcement norms in the United States.

If one were to consider intellectual property on the Internet, for example, an interesting cultural pattern might appear. The Internet may have an ethical culture of its $\mathrm{own}^{275}$ which, when merged with intellectual property norms in that forum, could lead to a complex set of behaviors that affect intellectual property protection. The anonymity and convenience available on the Internet may support deviant behavior, as users believe there is little chance of detection. ${ }^{276}$ The enormous access to all kinds of information without charge may also promote the view that everything on the Internet, including music, brand names, movies, and content from other people's materials, should be free. ${ }^{277}$

The cultural influence on attitudes towards copyright infringement is a palpable example. The stories that have made headlines over the last few years involving piracy of software and over the Internet are indicative of the challenges that copyright holders have faced in reaching the younger generation. ${ }^{278}$ Indeed, Gen Yers justify software piracy by viewing it not as a crime, but as payback to an industry that sets unfair

274. Id.

275. See Oliver Freestone \& Vincent-Wayne Mitchell, Generation Y Attitudes Towards E-ethics and Internet-related Misbehaviours, 54 J. BUS. ETHICS 121, 126 (2004).

276. Id.

277. See Mark F. Schultz, 21 BERKELEY TECH. L. J. 651, 659-61 (2006) (discussing the problem with file sharing on the Internet).

278. See, e.g., Brian Kladko \& Amy Klein, Record Labels Hit File Sharers in Wallet, THE REC., Aug. 29, 2004, at A1, A4 (discussing a 25-year-old construction worker accused of using filesharing software to download music and make 679 copyrighted music files available for others to download); Timothy McNulty, Recording Industry Plays Up Win in Piracy Case, PITTSBuRgh PoST-GAZETTE, Oct. 6, 2007, at A1 (discussing a 30-year-old single mother accused of using the file-sharing software to download and swap copyrighted music); Press release, U.S. Attorney's Office Dist. of Conn., Operation Higher Education: Maryland Man Involved in Online Piracy Ring is Sentenced (Aug. 7, 2007), http://www.usdoj.gov/usao/ct/press2007/20070807-1.html (discussing a 23-year-old convicted of organizing an underground online community which engaged in the large scale reproduction, modification, and distribution of copyrighted software over the Internet). 
prices. ${ }^{279}$ Moreover, college students "reflect[] an overall attitude in favor of illegally downloading and/or sharing music files." 280 Accordingly, social norms can have a significant effect on compliance. ${ }^{281}$

These kinds of changes in attitude about intellectual property are likely to affect not only protection, compliance, and enforcement norms, but may also have fundamental implications for innovation. In the long run, it would be interesting to evaluate whether such changes will lead to less innovation, what effect they may have on profit incentives, and the effect on relationships between those who invent or develop intellectual property and those who profit from them.

\section{B. Foreign Cultures and American Intellectual Property}

This kind of analysis might also provide guidance in thinking about the frustrations United States companies experience in dealing with the foreign enforcement of their intellectual property rights. In the developing world, for instance, where disregard for intellectual property rights is the rule rather than the exception, ${ }^{282}$ it is important to consider the cultural differences that create such barriers. The notion of intellectual property rights is "rooted in the culture, philosophy, and national character of the individual country."283 The protection of intellectual property rights should not necessarily be viewed as merely an enforcement problem, but one of compliance as well. To the extent that there is a disconnect between western views of intellectual property rights and the values attendant in those laws, and the values of developing countries, strategies to obtaining compliance may ultimately be more useful and successful than reliance on enforcement. ${ }^{284}$

Thus, in order for intellectual property rights to be meaningful in developing countries, it is important to understand the differences in their

279. See Freestone \& Mitchell, supra note 275.

280. R. Nicholas Gerlich, Nancy Turner \& Suresh Gopalan, Ethics and Music: A Comparison of Students at Predominantly White and Black Colleges, and Their Attitudes Toward File Sharing, 11 ACAD. EDUC. LEADERSHIP J. 1, 7 (2007).

281. See Schultz, supra note 277, at 655 (discussing social norms and music piracy); Lior Jacob Strahilevitz, Charismatic Code, Social Norms, and the Emergence of Cooperation on the FileSwapping Networks, 89 VA. L. REV. 505, 534-47 (2003) (discussing social norms in file swapping networks).

282. Talia H. Siegel, International Legal Issues That Can Impact Your On-Line Business, in SiXTH ANNUAL INTERNET LAW INSTITUTE, 265, 289 (2002).

283. Michael W. Smith, Note, Bringing Developing Countries' Intellectual Property Laws to TRIPs Standards: Hurdles and Pitfalls Facing Vietnam's Efforts to Normalize an Intellectual Property Regime, 31 CASE W. RES. J. INT'L L. 211, 225 (1999).

284. Id. 
value systems, organizational structures, and heritage. ${ }^{285}$ While it is commonly known, for example, that pirated products are often sold throughout Asia, and that educational campaigns and enforcement methods have failed to curb the practice, ${ }^{286}$ a look at Asian culture provides some insight into the underlying reason why the anti-piracy effort has been so difficult. ${ }^{287}$ In Asian culture, copying other people's works is viewed as a form of flattery rather than dishonest behavior, and " "the individual is subservient to the community." 288 This might help explain why members of those cultures reject the notion of individual property rights in ideas. ${ }^{289}$ Their ideals are fundamentally incompatible with an Anglo-American system that "singles out the creative individual for reward, values original expression, and believes that products are capable of disassociation from the artist to be sent through commerce."290

\section{VIII.CONCLUSION}

This Article applied sociological theories about employee theft to trade secret misappropriation to offer insights into what motivates employees to misappropriate trade secrets. Protecting trade secrets in today's workplace is a complex endeavor for businesses. Appropriate policies, processes, and technologies can be helpful. However, using a sociological perspective, the Article introduced another important element that has so far been overlooked - the people. Understanding the sociological dimension to trade secret misappropriation is a valuable part of the complex process of achieving optimal protection for trade secrets.

Using New Generation Employees as the point of study, this Article examined ways in which the attitudes of these younger generations might

285. Lauren Loew, Note, Creative Industries in Developing Countries and Intellectual Property Protection, 9 VAND. J. ENT. \& TECH. L. 171, 183-84 (2006).

286. See Carl Erik Heiberg, Note, American Films in China: An Analysis of China's Intellectual Property Record and Reconsideration of Cultural Trade Exceptions Amidst Rampant Piracy, 15 MiNN. J. INT'L L. 219, 241-43 (2006) (discussing high piracy rates in China and the failure of the enforcement system to reduce piracy levels).

287. See Assafa Endeshaw, Intellectual Property Enforcement in Asia: A Reality Check, 13 INT'L J. L. \& INFO. TECH. 378, 385 (2005) (“Imitation or copying from works of other people is not generally viewed as illegitimate or, even, questionable.").

288. Id. (quoting Arthur Wineburg, Jurisprudence in Asia: Enforcing Intellectual Property Rights, 5 U. BALt. InTELL. ProP. L.J. 25, 27 (1996)); Smith, supra note 283, at 226-28 (discussing Confucian ideals in Asian countries).

289. Endeshaw, supra note 287.

290. Smith, supra note 283, at 226-27. See also Peter K. Yu, From Pirates to Partners: Protecting Intellectual Property in China in the Twenty-First Century, 50 AM. U. L. Rev. 131, 211 (2000) (discussing the link between promoting individual rights and civil liberties in China and copyright compliance). 
affect trade secret protection, and observed that the indications suggest a likely increase in trade secret misappropriation cases. Understanding these generational differences is, therefore, vital to the process of discovering the most effective methods to teach the values that are necessary for successful trade secret protection and the efficient operation of business more generally. ${ }^{291}$ Finally, it explored the ways in which New Generation Employees may influence doctrinal development of trade secret law and the larger advantages of using a sociological approach to address the challenges to protection, compliance, and enforcement of intellectual property rights.

291. Bova \& Kroth, supra note 7, at 57. 